Journal of Social Sciences (COES\&RJ-JSS)

ISSN (E): 2305-9249 ISSN (P): 2305-9494

Publisher: Centre of Excellence for Scientific \& Research Journalism, COES\&RJ LLC

Online Publication Date: $1^{\text {st }}$ January 2018

Online Issue: Volume 7, Number 1, January 2018

https://doi.org/10.25255/jss.2018.7.1.28.41

\title{
"Let's let the students do by themselves" How to activate students with severe physical disability in the classroom?
}

\author{
Eija Häyrynen*, Kaarina Määttä** \& Satu Uusiautti***
}

* PhD, Special Education Teacher, Centre for Learning and Consulting, Finland. P.O. Box 106, 90049 Valteri, Finland. Email: eija.hayrynen@ valteri.fi

** PhD, Professor, Vice-rector, University of Lapland, Finland. P.O. Box 122, 96101

Rovaniemi, Finland. Email: Kaarina.Maatta@ulapland.fi ORCID: https://orcid.org/00000001-5658-7021

*** PhD, Professor, University of Lapland, Finland. P.O. Box 122, 96101 Rovaniemi, Finland. Email: Satu.Uusiautti@ulapland.fi ORCID: https://orcid.org/0000-0002-24096460

\begin{abstract}
:
A student with physical disability in the classroom can be a challenge for teaching arrangements. How to pay attention to these students' special needs and what are the best ways of supporting their learning? This research aimed at obtaining information about special education teachers' and other team members' experiences of everyday work with education of students with severe physical disability. This research was set one main question: How to activate students with severe physical disability in the classroom? The research participants of this research were the team members $(\mathrm{N}=16)$ who took care of 120 students participating the remedial courses during this research. The team members were special education teachers, various therapists, and social workers, who all worked with students with severe physical disability. The best practices to support students' activity and learning were teachers' positive and trusting attitudes, special solutions created in various school subjects, and multiprofessional collaboration, which are introduced and described in detail in the article.

Keywords:

Special education, severe physical disability, student, activation, inclusion.

Citation:

Häyrynen, Eija; Määttä, Kaarina; Uusiautti, Satu (2018). "Let's let the students do by themselves" How to activate students with severe physical disability in the classroom?; Journal of Social Sciences (COES\&RJ-JSS), Vol.7, No.1, pp:28-41; https://doi.org/10.25255/jss.2018.7.1.28.41.
\end{abstract}




\section{Introduction}

The inclusive school has received increasing support as schooling is developed. In Finland, it has been considered important that all children could go to their nearby schools regardless of their backgrounds or attributes. It is crucial that teachers are ready to face the difference in students and pay attention to their individuality so that every student can participate in schoolwork. Therefore, it is relevant to find suitable teaching methods for teachers (Florian, 2008). However, the concept of inclusion is still ambiguous, and the pros and cons of inclusive solutions are widely debated (see e.g., Määttä, Äärelä, \& Uusiautti, 2017). Waitoller and Artiles (2013) remind that inclusion is also culture- and context-bound and point out how theoretical analysis is still needed while practical implications require abundant local collaboration.

Physical disability does not always necessitate special arrangements are school but when it does, these needs have to be met in order to realize the principles of inclusion and students' participation. Physical disability is just one feature in students, and students' strengths and weaknesses may not have anything to do with their disabilities. However, severe physical disability may introduce several issues that have to be taken into consideration in schools. For example, Eunson (2015) and Miller and Bachrach (2006) describe motoric difficulties and additional challenges related to physical disability and influencing life and schoolwork in many ways.

What do the teaching and guidance of students with severe physical disabilities require from teachers in inclusive classrooms? How to create a learning atmosphere that activates and enhances learning in students with physical disabilities? These questions were at the core of research where the data were obtained in a special education school called Tervaväylä located in Oulu, Finland. The school arranges remedial education periods of various length to people with severe disabilities and is one of six units of the national Valteri Centre for Learning and Consulting, administered by the Finnish National Board of Education.

Valteri Centre for Learning and Consulting offers solutions for challenges in learning and involvement; multi-disciplinary services and training for professionals in the fields of early childhood education, teaching, and social and health care. Their services strengthen the equal school attendance and involvement of children and young people in neighborhood schools as well as support their family and friends. They work in partnership with municipalities to arrange general, intensified and special support in education.

Valteri Centre for Learning and Consulting is actively involved in projects and networks for developing special education. It participates in research projects that examine the rehabilitation supporting the functional capacity and learning of children and young people. One of the authors of this article, Dr. Häyrynen works as a special education teacher at Valteri and did her $\mathrm{PhD}$ research about the education of students with severe physical disability.

\section{Theoretical background: How does physical disability challenge schoolwork?}

Physical disabilities can be divided into cerebral palsy (CP), birth defects, neuromuscular disorders, and physical disabilities that are caused by accidents and somatic diseases (Cans, De-la-Cruz, \& Mermet, 2008). 
CP means permanent abnormal development or damage to the parts of the brain that control movement, balance, and posture, that emerges usually in early childhood in about 2-3 children of 1,000 (Rosenbaum et al., 2007). Myelomeningocele is a birth defect influencing among others the child's motor development (4/10,000 children) (Atta et al., 2016). Duchenne muscular dystrophy (DMD) is a severe type of muscular dystrophy occurring in 1/3,600 boys. The condition proceeds gradually as muscles weaken and by adolescence, children will need wheelchairs to move around (Moat et al., 2013; Nereo \& Hinton, 2003). In addition to orthopedic challenges (Miller \& Bachrach, 2006), physical disablitieis may involve additional problems that may occur, for example, as difficulties in linguistic skills (Hinton et al., 2004), movement control (Pirilä et al., 2011), sleeping (Mol et al., 2012), and oral-motor functioning (Bell et al., 2010).

When it comes to schooling of children with physical disabilities, challenges in communication (see e.g., De Bortoli et al., 2010; Wadnerkar et al., 2012), attention, memory, and visual processing (e.g., Majnemer et al., 2010) necessitate special solutions especially for math learning (Geary, 2010) and creation of social relationships (e.g., Bennet \& Hay, 2007; Diamond \& Hong, 2010). The goal of successful schoolwork is a challenge for teachers, school organization, methods, and physical school environment. Physical and socio-emotional safety, acceptance of difference, support, and encouraging and accepting atmosphere are crucial (Thapa, Cohen, Higgins-D'Alessandro, \& Guffey, 2012). Students' special needs and necessary aids have to be noticed at school.

In addition, connection with teachers and the whole school community is a major source of well-being in students with physical disabilities. An accepting social atmosphere has also a positive connection to learning outcomes and decreases risk behaviors (Allodi, 2010; Awartani, Whitman, \& Gordon, 2008).

Concrete help for students with physical disabilities may include, for example, looking for ways to have a good sitting position and opportunities work at the desk but even this can require a variety of multiprofessional expertise (Costigan \& Light, 2011). Being able to work in a good position is also a part of so-called postural treatment, that Hutton and Coxon (2011) call "postural care", and Pountney, Mandy, Green, and Gard (2009) "postural management program". Postural care, however, takes place throughout the day and night including various support and splints, supported sleeping and sitting positions, and standing with a standing frame.

Various treatment and remedial practices and aids aim at helping with difficulties caused by the physical disability (Palisano, Copeland, \& Galuppi, 2007). According to Maher, Evans, Sprod, and Bostock's (2011) research, usability of aids, collaboration with remedial personnel, and inclusion of remedial activities in one's daily schedule enhances adjustment to schoolwork. Accessibility of school, selection of materials, and light and sound conditions have to noticed when adjusting the learning environment (Elkins, 2005). Children's mental well-being has to be considered as well (Krakovsky, Huth, Lin, \& Levin, 2007).

For the teacher, a student with physical disability in the classroom can be a challenge. The school is a complex unit where different students, their family backgrounds and teachers meet. The quality of teachers is said to be to the single most important school variable to 
influence on student achievement. There are indicators like teacher qualifications and student performance, but there are also teacher-specific characteristics that are hard to measure, such as the ability to create effective learning environments for all students, be enthusiastic and creative and work together with colleagues and parents (OECD, 2005). The best way of searching solutions and better methods is to do research where teachers who have worked with students with physical disabilities are interviewed about their experiences. They are the best experts to tell about their perceptions and opinions on how to activate these students in the classroom.

\section{Method}

This was a qualitative research (see e.g., Creswell, 2009), that aimed at obtaining information about special education teachers' and other team members' experiences of everyday work with education of students with severe physical disability. This research was set one main question:

How to activate students with severe physical disability in the classroom?

The research was conducted in a special education school called Tervaväylä located in Oulu, Finland. This school arranges remedial courses of various lengths to students with severe physical disabilities in the form of multiprofessional activities. It is one of the six units of the national Valteri Centre for Learning and Consulting. Valteri is taken care of by the Finnish National Board of Education.

The core task of this school is to support the principle of being able to attend one's neighboring school in the northern Finland by providing education, learning materials, guidance, and remedial courses. The latter means periods that students, who usually attend school in their home counties, spend at Tervaväylä to find pedagogical methods that support their individual learning, to evaluate their remedial needs, and to assess their needs for aids and functionality of their aids. In addition to students themselves, the multiprofessional team covers the personnel from students' own schools, guardians, therapistst, and special teachers and other personnel responsible for remedial courses at Tervaväylä.

The research participants of this research were the team members $(\mathrm{N}=16)$ who took care of 120 students participating the remedial courses during this research. The team members were special education teachers, various therapists, and social workers, who all worked with students with severe physical disability. They had work experience from one year to 33 years (median 18 years).

The research data were obtained by interviewing the team members. The interview resembled a themed interview in which the interviewees were asked to talk about their experiences and perceptions of how to support students with severe physical disability. The themes covered in the interviews were functional methods to promote learning, teaching practices in various school subjects, issues concerning motor coordination, support for social skills learning, and remedial solutions. Background information about students received from their teachers and parents were used in the interviews.

Interviews concerned basic education students who had attended the remedial course in 2009-2010. They all had permanent physical disabilities. Some of the students attended the course twice, some only once during the school year. Of these 120 students, 63 (52\%) 
were boys and 57 (48 \%) were girls. Most of them (N=77) had CP while 20 of them had MMC. Other 15 had various disabilities, including muscular dystrophy.

The data analysis followed qualitative content analysis (e.g., Mayring, 2000). The interview data were reduced and categorized into themes. The purpose was to highlight the most important means of activating students as described the experts of special education themselves. The interview data were moved in a table that included original phrases, reduced plain expressions created from the original phrases, and the interpretation of the theme the phrases represented (Häyrynen, 2014). The experts' notions were given themes that eventually were combined into main categories representing teachers' positive and trusting attitudes, special solutions created in various school subjects, and multiprofessional collaboration. These categories are next presented as the main findings of the research.

\section{Results: Practices that support the learning in students with severe physical disabilities}

Based on the interviews, the best practices to support students' activity and learning could be categorized into three group: teachers' positive and trusting attitudes, special solutions created in various school subjects, and multiprofessional collaboration.

\section{Teachers' positive and trusting attitudes}

The start of studies should always be well planned. The willingness of school personnel and especially the teacher was considered a crucial factor of enhancing students' participation in schoolwork. Regardless of the possible scarcity of resources in schools, the teacher could create a positive learning atmosphere by showing his or her caring and trusting attitude. Teachers' attitudes were considered to have direct influence on students' attitudes.

It depends really much on how the adults work, and of course, the attitudes of other children. We do teach prejudices to our own children or acceptance in the same way. (1242)

The teachers described how students got various kinds of experiences of acceptance among other students. When changing groups during schooldays, one could become accepted in one students group and rejected in other. The teacher was considered the main example of showing acceptance and tolerance. The teacher's positive attitude was most clearly expressed by giving space and providing opportunities for special education students to participate in mutual school work:

You have to be able to guide the child in situations where he or she cannot act like others or how he or she is supposed to act. (52)

Difference can also be strength, and physical disabilities do not mean that students could not learn and advance in studies. Even experienced teachers like the ones interviewed in this research can marvel what students can do and learn:

Well, every year you like learn to find the great personalities in students. It is totally huge. (4478) 
The teachers' positive attitudes also mean that they have trust in students' survival and learning in practice. They are able to do things and teachers do not have to do everything for them:

Forgetting pitying. That is the last thing you can do to a child. If you start pitying the child like 'oh no, oh dear, you cannot do it' and you just do it for him or her. (3769).

For example, children, who communicate slowly, need time to prepare their opinion. The teacher can ask it after finds the student ready to answer. The teachers' ability to tactfully foresee how interaction in the classroom proceeds appeared significant. This could enable every student to express themselves.

We give time for those students if they have something to say. So, we wait as long as needed to get the answer right. Otherwise, they are not communicating really by themselves. Others will wait then. (4680)

The teachers who had positive attitudes to special education students pay attention to their special characteristics and needs when planning their daily schedules. Students with severe physical disabilities need more time than others to perform daily tasks and this time has to be provided during lessons or recesses. Teachers have to spare time for students to go to bathroom, eat peacefully, take care of their treatments during schooldays, moving from classroom to another, changing from a wheelchair to work chair and vice versa, putting clothes on and taking them off, etcetera. When the teacher knew the needs for time, students' various needs did not become unnecessarily emphasized.

Positive attitudes are also expressed by showing knowledge about necessary aids and how to use them. Students have their personal aids and, in addition to them, they need special computers with additional hardware and software. If the student has also a severe speech disorder, the opportunity write with toes or controls used with head will help communication. All kinds of practical solutions all the way from how to light the desk to how to carry equipment from a classroom to another require knowledge and trust in that technical solutions can be found and used for the students' good. For students, the teachers' positive attitudes toward them and familiarity with the necessary aids can become extremely important.

\section{Special solutions created in various school subjects}

The teacher's important task is to make the learning environment as accessible as possible by choosing suitable work methods especially in arts, PE, and crafts, supporting independent doing, and revising learning materials where possible.

Learning tasks and teaching methods of school subjects have to be reconsidered by acknowledging students' skills and special needs. For example, in arts, there is not just one right way because one student could use two hands and another student just one hand, while someone could only work by feet. Some students with severe physical disabilities could not use their hands or feet. When it came to PE, the severity of disabilities determined how segregated teaching should be and how much the students were expected to participate in same activities with others. Sometimes, the learning objectives had to be defined individually. Students could also adjust rules so that participation could become possible: 
There cannot be tasks in which the students would not do anything. Even if it was with mouth or foot or somehow. The absolute criterion is that the students could do at least something with their own limbs or mouth or head or something that moves. The same goes with music and PE. You should always find the way of having students do by themselves. You can always see it their faces, the joy of being able to do by themselves. (3675)

The students were given the chance of doing by themselves. Regardless of considering doing difficult or time-consuming, they were arranged opportunities to participate in everything that their peers could do. They could use feet to do dough or play drums. Sewing-machines could be used with mouth. In music lessons, equipment that could recognize voice from little movements and sticks could be taped in the keys of keyboard instrument. If students could not use hands or feet but could control their heads sufficiently, they could wear helmets or headbands where brushes or pens could be attached. All these solutions would require some effort from the people working closely with students.

Many times it causes some trouble to adults surrounding the children. So, that it is so much easier when doing, helping, and ignoring the children's need for growth. Keeping the children smaller and less demanding. (1094)

Students work and opinions were appreciated by the interviewees-whether the question was about art, household studies, science, or other school subjects. The importance of listening to students, tolerating errors, and giving time were the most crucial working methods from the perspective of student activation.

Actually the small ones, if you think about them, the small ones are at the beginning very satisfied with everything what they do, such as drawings. (5777)

In arts, the greatest joy is that whatever you produce is that the others would like it too. And if you see a tree in that, the others would realize that there is a tree even if there was basically nothing. (5636)

In household studies, various cutting boards with holders, knives with handles, mixers with stands, aprons with pockets to carry equipment and so on were small but important means to make studying easier. This research introduced numerous examples of how learning materials were selected according to students' skills and how to revise the materials when necessary. Aids such as digital or scanned textbooks, audiobooks, and other electronic materials prepared by teachers or school assistants were widely used in various school subjects. Learning materials were enlarged with copying machine, outlines of shapes could be drawn thicker, texts and pictures were outlined and the best possible angles for looking were searched to make learning easier. To help memorizing and understanding, issues to be learn were visualized and cut into smaller parts. Teachers could focus on just the most essential contents and rehearse them numerous times. They could utilize pictures and various images, memorizing rules, notes, notebooks, and reminders (e.g., in mobile phones) to enhance memorizing. Texts were underlined and numbered. 
Eventually, teachers became familiar with each student's learning and could design best solutions to support their learning. Likewise, routines were considered important to learning, memorizing, and activation. When certain things happened at certain time and in a certain manner, the everyday life became more organized. That supporting functioning and memorizing. For some students, the courses of days were structured with pictures at school and home, too.

Other practical solutions, such as having double textbooks (others at school and others at home), could make moving easier. Loose pages from textbooks could be placed higher on a special stand easier than whole textbooks. Those students who had big handwriting could have notebooks with bogger margins and lines. The amount of homework could be adjusted according to students' resources. They could also determine by themselves how much they could do homework. Preventive or remedial support for learning as well as support from a special education teacher or school assistant could help in learning. Taking exams in a quiet space, having extra time or answering orally, and having a school assistant to help with reading questions and writing answers helped students to perform better in exams.

\section{Multiprofessional collaboration}

Guiding and teaching students with severe physical disability necessitates multiprofessional collaboration. Important people in children's lives are parents, teachers from their own schools, and professionals from rehabilitation, health care, and social work units. Collaboration increased children's well-being. If also made teachers' work easier because it showed that teachers did not have to know everything.

The teachers undertand that they have students with special needs in their classrooms, and on the other hand, they understand that they do not have to know and master everything but they have these experts around them who they can use and consult to make that everyday work easier at school. And this communication and contacts should be reciprocal. (441)

Collaboration between teachers and school assistants was considered important because assistants had multiple tasks at school. They helped with daily chores, guided and helped during lessons and recess, revised and prepared learning materials, taught, interpreted students, served as scribes and read aloud texts, carried students' back bags, escorted students to school transportation and school trips. School assistants could also be friends.

Collaboration with parents had many features. They had to be guided and supported, and help them to cope as well.

Many times parents are quite worried about that their children can attend school. And if we say that the child needs more time or needs flexibility, their fear is that the child will be removed from school.

Teachers have to pay attention how to enhance collaboration between students in the classroom. Students with physical disabilities have to be able to move around freely in the school premises. The functional placement of their desks and chairs could enhance collaboration with classmates. The place selection would support interaction with others. 
The circumstances in which we are, in other words, removing all obstacles for moving. That is probably one thing that shows how the school welcomes the student. The place of students' desks is absolutely one thing to consider, and what kind of desk you have, what kind of chair do you sit and work, and were the student is in the classroom. Whether the student is in the same crowd with others or whether he or she has his or her own place there somewhere, in the classroom but in a way that does not belong clearly in the crowd. (457)

Collaboration also requires good behavior from the students with physical disabilities. The teachers described the methods that they used for guiding and teachings students' social skills and positive behavior in social situations. They were taught how to take turns, accept other students, apologize and forgive, and ask somebody to be a friend.

Students were encouraged to take contact. Teamwork was practices with others. There were numerous means to practice social interaction and communality, such as buddy programs, anti-bullying actions, collaborative learning methods, and pair working. The interviewees also mentioned that picturing various situations and analyzing them with pictures had worked well. They also had recesses inside, when some of the students could spend the recess with students with physical disability. Otherwise, students with physical disability could start putting on clothes a little bit earlier so that they would make it to recess outside.

The students' ability to ask for help was considered important to collaboration and activation. At the beginning, their needs for help were greater, but as their abilities increased, these needs decreased. However, some students' abilities decreased or they could have illnesses that increased their needs for help. Therefore, the ability to ask for help was a skill that they practiced consciously. Students were taught how to ask for help literally phase by phase all the way from approaching other people to expressing themselves. This way the students would also learn to take responsibility over themselves and their learning, too. On the other hand, adults needed sensitivity to notice when students were ready for such responsibility.

At first, they want to bear some of the responsibility. That is something, when they have the willingness to take care. But that is a predetermined process too. It is not any abracadabra, they need to be given time for that, too. (1629)

The ability to guide the helping adult and to master one's own aids and functions were important for collaboration. Assisting persons' expertise is to be present in a way that each situation requires. Many things necessitate numerous repetitions and guidance with words and by hands. Feelings of pity or wish to help excessively had to recognized because these would prevent students from learning to work independently.

Making the child feel safe. Even if the child needs wide support, but knows what he or she wants and how to do these things so that they would happen safely. And the child would not have to be afraid when people change around him or her. (844) 
Remedial activities as a part of schooling would work the best so that students' own therapists were active about starting the collaboration with teachers and school assistants at the beginning of the school year. Collaboration was always local and based on students' special needs. Multiprofessional collaboration had to allocated sufficiently time and space.

\section{Discussion}

In this study, three main perspectives could be named as the most important means of activating students with severe physical needs. Teachers' positive and trusting attitudes, special solutions created in various school subjects, and multiprofessional collaboration seemed to support students learning and abilities in general as well as their participation and social skills. The practical tips and methods described in results were considered functional but finding the right way of supporting each student also needed effort. However, without the positive and optimistic attitudes that appreciate students' own features and abilities none of the efforts will function in full.

In this study, the interviewees were experts who considered teaching arrangements and practical work in schools in the light of 120 cases of students with severe physical disabilities. Kvale and Brinkmann (2009) emphasize that confidentiality and evaluation of research have to be followed throughout the whole research process. The purpose of this research was to get a holistic picture of everyday life at school so that students could be supported the best. The core question is therefore whether this data provided sufficiently and correct information about this. As the findings showed, the data was quite versatile and practical, and thus considered to meet the objectives of this study.

It is also relevant to evaluate if another researcher would have obtained different kind of data or if different participants would have provided various information (Kvale \& Brinkmann, 2009). Interview situations are always unique events between two persons. In this study, the teachers' and other experts' perceptions and experiences were in the focus. The reality thus was constructed in social interaction between the interviewee and the interviewer (see e.g., Creswell, 2009). The information is analyzed and interpreted by researchers: in this case, by the main researcher who had been working with students with physical disability for years and professors with special expertise of education and educational psychology. The combination of research team expertise was considered to enhance the depth and objectivity of analyses.

\section{Conclusions}

This research highlighted the teacher's role in how to active students with severe physical disabilities. Also students own features were important when considering their opportunities to participate and study in inclusive school communities. Good social skills, acceptance of oneself, talents, and abilities to ask for help and master one's aids would certainly support students' coping at school (cf., Florian, 2008). This study showed that social skills could be practiced at school, and this has also been noticed in earlier studies too (Diamond \& Hong, 2010; Diamond, Hong, \& Tu, 2008; Hollingsworth \& Buysse, 2009).

However, the significance of adults who created opportunities to active participation cannot be emphasized too much (WHO, 2007). As this study showed, it requires effort: communication situations have to predicted and planned, necessity of accessibility in the school environment has to be understood, work methods in each school subject have to be 
chosen so that the students can work, and enough time has to be given to students to complete tasks - in other words, remedial activities have to be widely used in schools (see also Costigan \& Light, 2011; Hutton \& Coxon, 2011; Maher et al., 2011). Attention to each student as an individual is at the core of all this (cf., Imms et al., 2016). When the aforementioned preconditions become fulfilled, the school culture can be called activating and inclusive.

Experts participating in this research expressed how they enjoyed their work and felt joy when seeing successes as students progressed in their learning and studies. Students' increasing activity was perceived rewarding.

In order to be able to welcome all students, issues at the organizational level and practical pedagogical choices have to be reconsidered (cf., Brady, 2005; Dorczak, 2013). Teachers need pedagogical tact and sensitivity as well as constant in-service training and learning. In the school community, this means that teachers' well-being has to paid adequate attention, too, by ensuring necessary resources and support for them. Inclusion cannot become fulfilled if teachers do not know how to face and successfully pay attention to various learners or are not sufficiently supported to do that (Uusiautti \& Määttä, 2018). Sharing of practical knowledge and skills of special education is needed: positive attitudes will emerge only if there is good ground for it-support-, method-, and collaborationwise.

\section{References}

Allodi, M. W. (2010). The meaning of social climate of learning environments: Some reasons why we do not care enough about it, Learning Environments Research, 13 (2), pp. 89-104. doi: 10.1007/s10984-010-9072-9

Atta, C. A. M., Fiest, K. M., Frolkis, A. D., Jette, N., Pringsheim, T., St Germaine-Smith, C., Rajapakse, T., Kaplan, G. G., and Metcalfe, A. (2016). Global birth prevalence of spina bifida by folic acid fortification status: a systematic review and meta-analysis, American Journal of Public Health, 106 (1), 25-34. doi: 10.2105/AJPH.2015.302902

Awartani, M., Whitman, C. V. and Gordon, J. (2008). Developing instruments to capture young people's perceptions of how school as a learning environment affects their wellbeing, European Journal of Education, 43 (1), 51-70. doi: 10.1111/j.14653435.2007.00337.x

Bell, K. L., Boyd, R. N., Tweedy, S. M., Weir, K. A., Stevenson, R. D., and Davies, P. S. (2010). A prospective, longitudinal study of growth, nutrition and sedentary behaviour in young children with cerebral palsy, BMC Public Health, 10 (1), 179. doi: 10.1186/14712458-10-179

Bennet, K. S., and Hay, D. A. (2007). The role of family in the development of social skills in children with physical disabilities, International Journal of Disability, Development \& Education, 54 (4), 381-397. doi: 10.1080/10349120701654555

Brady, P. (2005). Inclusionary and exclusionary secondary schools: the effect of school culture on student outcomes, Interchange, 36 (3), 295-311. doi: 10.1007/s10780-0056867-1 
Cans, C., De-la-Cruz, J., and Mermet, M.-A. (2008). Epidemiology of cerebral palsy, Paediatrics and Child Health, 18 (9), 393-398. doi: 10.1016/j.paed.2008.05.015

Costigan, F. A., and Light, J. (2011). Functional seating for school-age children with cerebral palsy: An evidence-based tutorial, Language, Speech \& Hearing Services in Schools, 42 (2), 223-236. doi: 10.1044/0161-1461(2010/10-0001)

Creswell, J. W. (2009). Research design: qualitative, quantitative, and mixed methods approaches, Thousand Oaks, CA: Sage.

De Bortoli, T., Arthur-Kelly, M., Mathisen, B., Foreman, P., and Balandin, S. (2010).

Where are teachers' voices? A research agenda to enhance the communicative interactions of students with multiple and severe disabilities at school, Disability and rehabilitation, 32 (13), 1059-1072. doi: 10.3109/09638280903410730

Diamond, K. E., and Hong, S.-Y. (2010). Young children's decisions to include peers with physical disabilities in play, Journal of Early Intervention, 32 (3), 163-177. doi: $10.1177 / 1053815110371332$

Diamond, K. E., Hong, S.-Y., and Tu, H. (2008). Context influences preschool children's decisions to include a peer with physical disability in play, Exceptionality, 16 (3), 141155.

Dorczak, R. (2013). Inclusion through the lens of school culture. In G. Mac Ruairc, E. Ottesen, \& R. Precey (Eds.), Leadership for inclusive education. Values, vision and voices. Studies in inclusive education (pp. 47-57). E-book.

Elkins, J. (2005). Inclusive education in Queensland: Where are we going and how will we get there, Social Alternatives, 24 (4), 45-49.

Eunson, P. (2015). The long-term health, social, and financial burden of hypoxicischaemic encephalopathy, Developmental Medicine \& Child Neurology 57 (S3), 48-50. doi: $10.1111 /$ dmcn.12727

Florian, L. (2008). Special or inclusive education: future trends, British Journal of Special Education, 35 (4), 202-208. doi: 10.1111/j.1467-8578.2008.00402.x

Geary, D. C. (2010). Mathematical disabilities: Reflections on cognitive, neuropsychological, and genetic components, Learning and Individual Differences, 20 (2), 130-133. doi: 10.1016/j.lindif.2009.10.008

Hinton, V. J., De Vivo, D. C., Fee, R., Goldstein, E., and Stern, Y. (2004). Investigation of poor academic achievement in children with Duchenne muscular dystrophy, Learning Disabilities Research \& Practice, 19 (3), 146-154. doi: 10.1111/j.1540-5826.2004.00098.x Hollingsworth, H. L., and Buysse, V. (2009). Establishing friendships in early childhood inclusive settings: What roles do parents and teachers play? Journal of Early Intervention, 31 (4), 287-308.

Hutton, E., and Coxon, K. (2011). 'Posture for learning': meeting the postural care needs of children with physical disabilities in mainstream primary schools in England -a 
research into practice exploratory study, Disability \& Rehabilitation, 33 (19/20), 19121924. doi: 10.3109/09638288.2010.544837

Häyrynen, E. (2014). Kun oppilaan liikuntavamma haastaa. Monitoimijaisen verkoston käsityksiä oppimisympäristöön liittyvistä vaatimuksista ja hyvistä käytännöistä [When a pupil's physical disability challenges. Perceptions of a multi-professional network about requirements and good practices related to the learning environment], Rovaniemi: Lapland University Press.

Imms, C., Adair, B., Keen, D., Ullenhag, A., Rosenbaum, P., and Granlund, M. (2016). 'Participation': a systematic review of language, definitions, and constructs used in intervention research with children with disabilities, Developmental Medicine \& Child Neurology, 58 (1), 29-38. doi: 10.1111/dmcn.12932

Krakovsky, G., Huth, M. M., Lin, L., and Levin, R. S. (2007). Functional changes in children, adolescents, and young adults with cerebral palsy, Research in Developmental Disabilities, 28 (4), 331-340. doi: 10.1016/j.ridd.2006.03.005

Kvale, S., and Brinkmann, S. (2009). Interviews: Learning the craft of qualitative interviewing, London: Sage.

Maher, C. A., Evans, K. A., Sprod, J. A., and Bostock, S. M. (2011). Factors influencing postural management for children with cerebral palsy in the special school setting, Disability and Rehabilitation, 33 (2), 146-158. doi: 10.3109/09638288.2010.490868

Majnemer, A., Shevell, M., Law, M., Poulin, C., and Rosenbaum, P. (2010). Level of motivation in mastering challenging tasks in children with cerebral palsy, Developmental Medicine \& Child Neurology, 52 (12), 1120-1126. doi: 10.1111/j.14698749.2010.03732.x

Mayring, P. (2000). Qualitative content analysis, Qualitative Social Research, 1 (2). Retrieved from: http://www.qualitative-research.net/index.php/fqs/article/view/1089/2386 Miller, F., and Bachrach, S. J. (2017). Cerebral palsy: A complete guide for caregiving, Baltimore: A Johns Hopkins University Press.

Moat, S. J., Bradley, D. M., Salmon, R., Clarke, A., and Hartley, L. (2013). Newborn bloodspot screening for Duchenne muscular dystrophy: 21 years experience in Wales (UK), European Journal of Human Genetics, 21(10), 1049-1053. doi: 10.1038/ejhg.2012.301

Mol, E. M., Monbaliu, E., Ven, M., Vergote, M., and Prinzie, P. (2012). The use of night orthoses in cerebral palsy treatment: Sleep disturbance in children and parental burden or not? Research in Developmental Disabilities, 33 (2), 341-349. doi: 10.1016/j.ridd.2011.10.026

Määttä, K., Äärelä, T., and Uusiautti, S. (2017). What happens to special education: will inclusion be the solution? Asian Journal of Education and e-Learning, 5 (5), 141-149. 
Nereo, N. E., and Hinton. V. J. (2003). Three wishes and psychological functioning in boys with Duchenne muscular dystrophy, Journal of Developmental and Behavioral Pediatrics, 24 (2), 96-103.

OECD. (2005). Teachers matter. Attracting, developing and retaining effective teachers. http://www.oecd.org/education/school/34990905.pdf

Palisano, R. J., Copeland, W. P., and Galuppi, B. E. (2007). Performance of physical activities by adolescents with cerebral palsy. Physical therapy, 87 (1), 77-87. doi: 10.2522/ptj.20060089

Pirilä, S., van der Meere, J. J., Rantanen, K., Jokiluoma, M., and Eriksson, K. (2011). Executive functions in youth with spastic cerebral palsy, Journal of Child Neurology, 26 (7), 817-821. doi: 10.1177/0883073810392584

Pountney, T. E., Mandy, A., Green, E., and Gard, P. R. (2009). Hip subluxation and dislocation in cerebral palsy - a prospective study on the effectiveness of postural management programs, Physiotherapy Research International, 14 (2), 116-127. doi: 10.1002/pri.434

Rosenbaum, P., Paneth, N., Leviton, A., Goldstein, M., Bax, M., Damiano, D., and Jacobsson, B. (2007). A report: the definition and classification of cerebral palsy April 2006, Developmental Medicine \& Child Neurology, 49 (S109), 8-14. doi: 10.1111/j.1469-8749.2007.tb12610.x

Thapa, A., Cohen, J., Higgins-D’Alessandro, A., and Guffey, S. (2012). School climate research summary: August 2012, School Climate Brief, 3, 1-21.

http://www.schoolclimate.org/climate/documents/policy/sc-brief-v3.pdf

Uusiautti, S., and Määttä, K. (Eds.) (2018, in press). New methods of special education, Frankfurt am Main: Peter Lang Publishing.

Wadnerkar, M. B., Pirinen, T., Haines-Bazrafshan, R., Rodgers, J. and James, D. (2012). A single case study of a family-centred intervention with a young girl with cerebral palsy who is a multimodal communicator, Child: Care, Health \& Development, 38 (1), 87-97. doi: $10.1111 / \mathrm{j} .1365-2214.2011 .01214 . \mathrm{x}$

Waitoller, F. R., and Artiles, A. J. (2013). A decade of professional development research for inclusive education: a critical review and notes for a research program, Review of Educational Research, 83 (3), 319-356. doi: 10.3102/0034654313483905

WHO. (2007). International classification of functioning, disability and health: children \& youth version ICF-CY, World Health Organization. http://apps.who.int/iris/bitstream/10665/43737/1/9789241547321_eng.pdf 